available for the general reader and the student to reviow critically the earliest material from East Anglia which, it is claimed, shows evidence of human liandiwork, and to give an account of the investigations of the Abbé Breuil on the gravels of the Somme and their bearing on and consequences in determining the dating of paliolithic industries, which, it would seem, must now be subjected to considerable revision. A summary account of the latter research by the Abbe Breuil himself for the benefit of British archæologists appears in the current issue of the Proceedings of the Prehistoric Society. Further, Dr. Wright, whilo pointing out that the familiar classification of palæolithic implements, based on the material from France, is too deeply rooted in archæological studies to be ignored in a general survey, adopts and expounds the core-flake classification of implements, entering fully into its technological, classificatory and ethnical implications, as affecting the world-wide study of stone age cultures.

Dr. Wright's critical examination of the evidence and of the development of hitherto accopted theory, consequent upon recent archæological discovery and discussion, gives this manual an authoritativo position, and makes it, at present, uniquo in the English literaturo.

Studies on the Ice Age in India and Associated Human Cultures

By H. do Terra and T. T. Paterson. (Publication No. 493.) Pp. $\mathrm{xi}+354+56$ plates. (Washington, D.C. : Carnegie Institution, 1939.)

A S Dr. do Terra and Mr. Paterson themselves $A$ have already summarized the main results of their investigations for the benefit of the readers of Nature, it would be $n$ work of supererogation to deal here with their report in its final form in detail. It will perhaps suffice to indicate its scope and distribution of topics. The report is in five parts, of which the first deals with the ice age in southwestern Kashmir; the second covers conditions in north-west and peninsular India, so far as indicated by investigations in two main regions, the Soan basin and the Indus river; the third section deals with the Nerbada valloy Pleistocene; Part iv is concerned with the stratigraphy and typology of Madras; and the fifth and final section is devoted to the late stone age sites of Sukkur and Rohri on the lower Indus, a proto-neolithic civilization, which it is held may suggest an indigenous evolution and not a foreign origin for Mohenjo-daro and the Indus civilization.

\section{The Mind of Primitive Man}

By Franz Boas. Revised edition. Pp. $x+285$. (Now York : Tho Macmillan Company, 1938.) 12s. 6d. net.

$T$ is a remarkable tribute to the enduring qualities 1 of the work of the veteran American anthropo. logist that a new edition of this book should be demanded so many years after its original publication, and when so many developments have supervened in anthropological thought in the interval. The book on its first appearance attained a position of consider. able authority not only on account of the originality of its views on the calibre of the mind of primitive man, but also for its statement of the results of the author's observations on changes in the physical characters of immigrants and their descendants after entry into the United States. In the now edition, which has been thoroughly revised, Prof. Boas donounces with unimpaired vigour, in a review of anthropological theories of race, the perversion of racial theory in the interests of political prejudice and propaganda.

\section{(I) Masques Dogons}

Par M. Griaule. (Université de Paris : 'Travaux et Mémoires de l'Institut d'Ethnologie, Tomo 33.) Pp. $\mathbf{x}+896+32$ plates. (Paris: Institut d'Ethnologio, 1938.) 275 franes.

(2) Jeux Dogons

Par M. Griaule. (Université do Paris : 'T'rævaux et Mémoires de l'Institut d'Ethnologio, Tome 32.) $\mathbf{P}_{\mathrm{p}}$. viii $+290+12$ plates. (Paris : Institut d'Ethnologio, 1938.) 87.50 francs.

(1) THE masked dances which aro the ritual mani-

1 festation of the ancestor cult of the Dogon of the French Sudan have been made the subject of an elaborate study by M. Griaule. This study is based upon material collected in the course of three expeditions between 1931 and 1937. Although the Dogon all recognize and worship a supreme creating deity, the masks, and the dances in which thoy figure, and tho ancestral cult with which they aro associated, take a much more prominent place in their daily life and thought. Of the ancestral spirits, some are regarded as immortal, while others, who belong to the time after death appeared on the earth, aro held to be mortal. From the relations to the immortal ancestors, who have returned to exercise a protective function over their descendants, has originated a totemic cult; while the cult of the masks and tho dances in which thoy are used is directed to those of the ancestors who have suffered death.

II. Griaulo has made a comprehensive study of an oxtremely complicated system of religious beliefs, in which nyama, a belief akin to the mana of Pacific peoples, plays an important part. Students of the history of religions will find here much of the greatest interest.

(2) M. Griaule's record of Dogon children's games, as played in the Bandiagara-Sanga-Kassa district, a region $80 \mathrm{~km}$. long by $10 \mathrm{~km}$. broad, is no less detailed than his study of Dogon masks and dances. It includes a large number of games of every type and variety, some of them belonging to groups which have a very wide geographical distribution. Among the games appearing hero which havo a special interest are those of a proverbial character, involving a guessing competition, these being especially expressive of Dogon mentality. The author notes a large number of string figures, which have been both carefully recorded and fully illustrated. M. Griaule's monograph is a valuable and very instructive contribution to the literature of a fascinating study. 